\title{
Contamination of heavy metals and metalloids of groundwater in the vicinity to the wild landfill of El Hajeb city (Morocco)
}

\author{
A. Gamar ${ }^{1,2} *$, T. Zair ${ }^{1,2}$, M. El Kabriti ${ }^{3}$, F. El Hilali ${ }^{1,2}$ \\ ${ }^{I}$ Research team of Chemistry of the Bioactive Molecules and the Environment Department of Chemistry, \\ Moulay Ismail University, Faculty of Sciences, ZitouneMeknes, MOROCCO \\ ${ }^{2}$ Laboratory of Chemistry of Materials and Biotechnology of Natural Products (Chima-Bio) Department of Chemistry, \\ Moulay Ismail University, Faculty of Sciences, ZitouneMeknes, MOROCCO \\ ${ }^{3}$ National Laboratory of the Studies and the Monitoring of the Pollution (NLSMP), \\ Ministry Delegate in Charge of the Environment Morocco Al Irfane-City, Rabat, MOROCCO \\ ${ }^{*}$ Corresponding Author's e-mail: abdgam@yahoo.fr, Tel + 212-609147740 \\ ORCID iDs: https://orcid.org/0000-0002-1377-9151 (Gamar), https://orcid.org/0000-0002-7315-1188 (Zair), https://orcid.org/0000-0002-7301-2588 (El Kabriti), \\ https://orcid.org/0000-0002-4091-2612 (El Hilali)
}

\begin{abstract}
Many previous studies have shown that leachate from uncontrolled landfills are among the most polluting source of groundwater. In this context, the quality of groundwater regarding metallic trace elements has been studied near the wild dump of El Hajeb city (Morocco). At the first campaign of sampling (May-2015 to January-2017), eighty-six water samples were collected from the groundwater of stations (wells, boreholes and springs) around the dump and along the water table flow. The contents in $\mathrm{Cd}, \mathrm{Cr}, \mathrm{Cu}$, $\mathrm{Mn}, \mathrm{Ni}, \mathrm{Pb}, \mathrm{As}, \mathrm{Zn}, \mathrm{Hg}, \mathrm{Ag}, \mathrm{Sn}$ and Fe were determined by ICP-AES technique. The results showed that the waters of the stations located very close to the wild landfill contained a high metal load $(\mathrm{Cd} \max =5.43 \mathrm{~g} / \mathrm{L}, \mathrm{Cr} \max =254.16 \mathrm{~g} / \mathrm{L}, \mathrm{Mn} \max =663.12$ $\mathrm{g} / \mathrm{L}$, Ni $\max =261.07 \mathrm{~g} / \mathrm{L}, \mathrm{Pb} \max =91.11 \mathrm{~g} / \mathrm{L}$ ) exceeding the peremptory Moroccan norms. On the other hand, some high correlations have been revealed, like the lead and the arsenic that are negatively correlated with $\mathrm{SO}_{4}$ and the strong positive correlation between $\mathrm{Fe}$ and $\mathrm{Mn}$. The present study provides a characterization of groundwater in heavy metals and Metalloids intended for irrigation and human consumption.
\end{abstract}

Keywords: Groundwater, metals elements, correlation, leachates, landfill, pollution.

DOI: http://dx.doi.org/10.4314/ijest.v12i4.4

Cite this article as:

Gamar A., Zair T., El Kabriti M., El Hilali F. 2020. Contamination of heavy metals and metalloids of groundwater in the vicinity to the wild landfill of El Hajeb city (Morocco). International Journal of Engineering, Science and Technology, Vol. 12, No. 4, pp. 41-53. doi: 10.4314/ijest.v12i4.4

Received: September 9, 2020; Accepted: October 7, 2020; Final acceptance in revised form: October 20, 2020

\section{Introduction}

Metals are omnipresent in natural waters; however, their concentrations are generally very low, which explains their designation as "trace metals". They are commonly present in the Earth's crust, also the alteration and erosion of the rocks naturally feeds natural waters into trace metals (Elder, 1988). On the other hand, the problem of contaminated water is now very worrying because inputs from anthropogenic activities to have increased the levels of heavy metals and metalloids in the environment tremendously (Prater, 1975; Sayyed and Sayadi, 2011). They cannot be biodegraded and therefore persist in the environment for long periods. 
Gamar et al. / International Journal of Engineering, Science and Technology, Vol. 12, No. 4, 2020, pp. 41-53

Moreover, even though trace metals are needed by the body to satisfy its nutritional requirements, high doses led to health hazards, which are sometimes lethal (Ackah et al., 2011). The main threat comes from exposure of lead, cadmium, cobalt, nickel, mercury, arsenic. Other trace elements have been extensively studied and many authors (Larocque and Rasmussen, 1998; US EPA, 2002; WHO, 2008) have reviewed their effects on human health regularly. The World Health Organization estimates that more than ten percent of preventable diseases are due to poor quality of the local environment, whose inadequate waste management is a major contribution element. Leachate generated is the main vehicle for the transport of metallic pollution. It contains a significant amount of both organic and inorganic pollutants plus heavy metals. So soil and groundwater pollution, by percolation of these waste liquids, are two major risks to be feared and the highest concentrations of heavy metals occur in leachate from young landfills in the acid fermentation phase and at low $\mathrm{pH}$ (Erses and Onay,2003). This issue also even deteriorated with the improper disposal of electronic products, leading to the release of high levels of heavy metals (Awasthi et al., 2016; Wittsiepe et al., 2017).

The quantity and quality of leachate are influenced by several factors, such as the composition of the waste, biochemical processes that occur in the degradation stages of the waste, amount of moisture, and the local parameters (Ma et al., 2018). Leachate migration in open dumping sites is a dominant source of heavy metals in surface and groundwater, soil, and plants (Esakku et al., 2003; Kanmani and Gandhimathi, 2012; Slack et al., 2005).If plants uptake heavy metals from polluted soil, there is a high possibility of heavy metals transferring to the human food chain through the consumption of vegetation or animals (Chary et al., 2008; Nica et al., 2012). Indeed, according to a recent study carried out near Municipal Solid Waste Landfill Vientiane, Laos (Vongdala et al., 2019) the vegetable aquatic, which is consumed by the nearby villagers, was seriously contaminated by $\mathrm{Cr}, \mathrm{Pb}, \mathrm{Cu}$, and $\mathrm{Zn}$, as the accumulation of these toxic metals was elevated to much greater levels as compared to the WHO standards. Therefore, areas close to landfills have a greater chance of water pollution due to the possible contamination source of leachate originating from the dumpsites. Thus, leakage of leachate can cause pollution of nearby groundwater and surface water, agriculture, and natural ecosystems, especially when the leachate is released uncontrolled, and hence, can cause environmental health issues in many developing countries (Adamcová et al., 2017; Oyeku and Eludoyin, 2010; Samadder et al., 2017). In addition to the large amount of heavy metal pollution originating from leachate, the degradation of a large amount of biodegradable material in the landfills also played a role (Liao et al., 2016).

Biodegradation involves the use of a large amount of oxidant, for example, oxygen, in the aquifer matrix, which is in a relatively poorly ventilated groundwater table. This induces reducing conditions in the groundwater table, and the existing state of the affected groundwater by heavy metals is disturbed. This results in the heavy metals covering unusually high quantities of large particles, activated and non-activated colloids, and dissolved small particles. This can cause the heavy metals to be adsorbed on the pore of the aquifer (Boatenget al., 2019).

This study contributes to the existing literature by providing a better understanding of the groundwater potential pollution from leachates generated by wild landfill by exploring a hypothesis to show that the influence of leachates on ecosystems can be compounded by the infiltration through the soil. The paper contributes also the first logical analysis of the groundwater quality parameters near the wild landfill of El Hajeb city. In addition, the study demonstrates the preliminary ecosystem condition of the groundwater and highlights adverse environmental and public health consequences of co-disposal of metals and electronic wastes at improperly engineered municipal landfills. The research results provide a scientific foundation for protecting and managing groundwater resources in El Hajeb-area and similar areas, and we hope provides a good example for further groundwater contamination research by heavy metals and metalloids in Morocco in the coming years.

\section{Materials and methods}

Although the city of El Hajeb (Morocco) occupies an important place, both by its geographical location between the Atlas Mountains and the plain of Saïs (Fig. 1) and by its water resources huge, it has not escaped the problem of the leak of leachates. Its dump is uncontrolled and open-air, where all types of waste are discarded in the raw state. More or less informally, this discharge was put into operation at the beginning of the year 2005. Since then, its institutional status has not clarified; sometimes described by some as "wild dump", sometimes presented by others as a "public dump". It receives around 35 tons of waste daily, of which $78.1 \%$ is organic matter. The sources of solid waste include household waste at 90\% (Gamar et al., 2017a).

Its current state is one of the major problems that the study area is experiencing in terms of environmental damage. The accumulation of waste does not find internal and external stability. Indeed, the internal contact of the wastes by uncontrolled fires produce fumes containing dioxins and other toxic substances and the external contact of the wastes with the soil permeable generate the formation of leachates flow unnoticed to the surface and groundwater where they are lost by transferring the whole and the quintessence of their lethal poisons. The detection in the region of the city of El Hajeb of significant levels of heavy metals and metalloids in waters destined for human consumption has led to the realization of a study to identify potential risk areas. This area has already been the subject of a detailed potential investigation program including:

- A study characterizing the leachates generated by the wild landfill of the city of El Hajeb (Gamar et al.,2017a, 2017b, 2017c \& 2017d),

- A study of the physicochemical quality of groundwater adjacent to the same landfill (Gamar et al., 2018). 
These two studies have demonstrated the correlation between the abnormal values of certain physicochemical parameters in groundwater and the existence of significantorganic and inorganic concentrations in leachates generated by waste from the wild landfill.

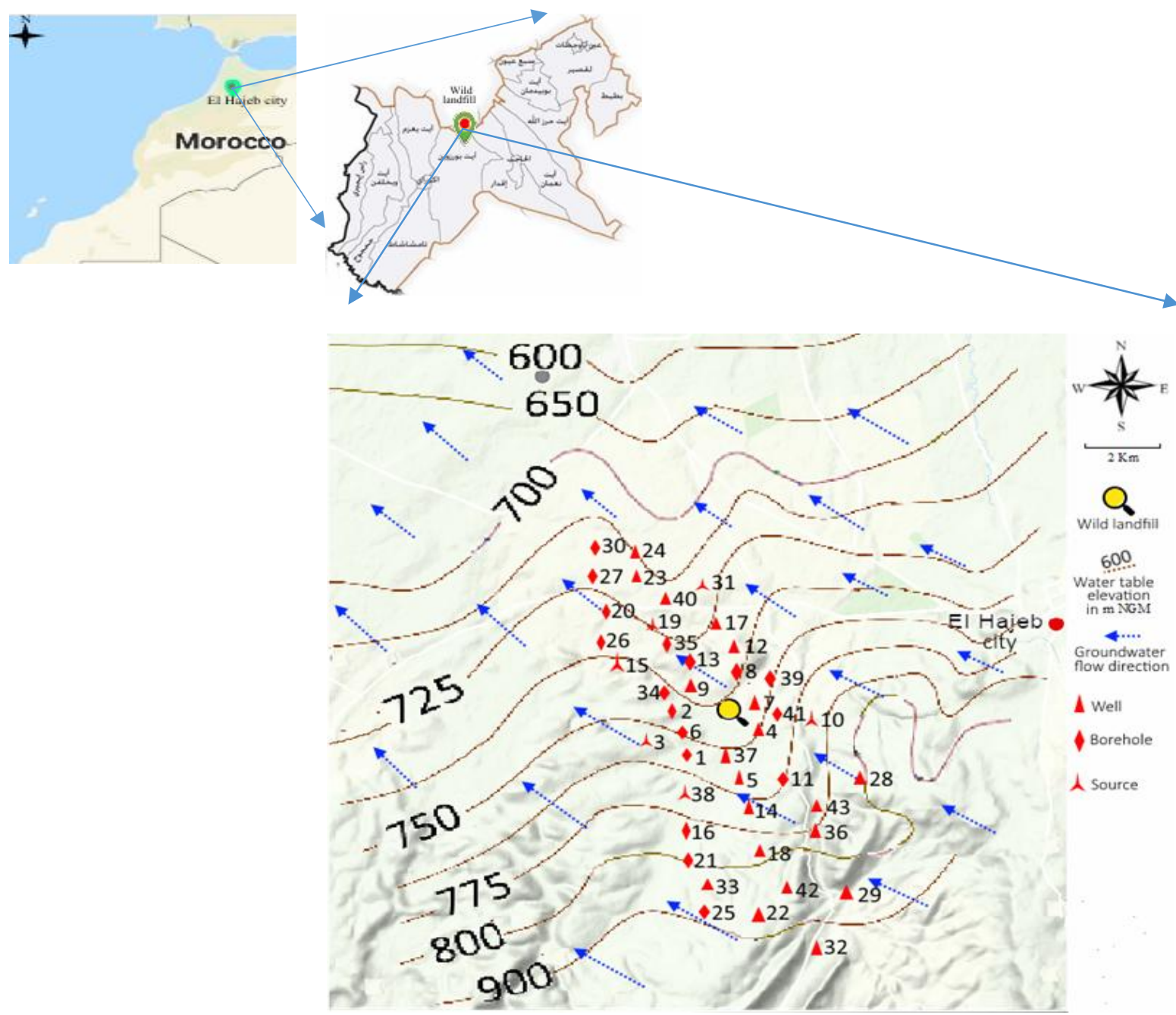

Fig. 1. Location of landfill and of groundwater stations

The investigation program presented in this study therefore consists of verifying the possible presence of undesirable elements in groundwater for the whole region by carrying out the following operations:

- The establishment of an inventory of the main water points for human consumption (wells, springs and boreholes number of 43) upstream and downstream of the landfill,

- The sampling and multi-element analysis (14 analysed elements) covering the entire sector studied.

The sampling campaign took place during 5 seasons, from the beginning of 2015 until the end of 2017 and concerned 43 sampling stations (wells, boreholes and springs), with a total of 86 samples. Their description and their geographic position (Lambert coordinates) on the Table 1 . The analyses to the number of 1204 are carried out as follows:

- The portions are taken of the samples of $50 \mathrm{ml}$ filtered at $0.45 \mu$ and acidified with $\mathrm{HNO}_{3}(\mathrm{pH}<2)$ then exposed to digestion, at high temperature;

- The instrument Perkin Elmer Optima 5300 DV ICP-OES system was calibrated with a commercial multi-element standard solution;

- Five aqueous standard solutions of concentrations: 0, 10, 25, 50, and $100 \mu \mathrm{g} / \mathrm{L}$ was prepared using ultra-pure (Fig. 2) water in $2 \%(\mathrm{v} / \mathrm{v}) \mathrm{HNO}_{3}$ (purity $65 \%$ ); the curve was obtained with regression coefficient, $\mathrm{R}^{2}=0.999$;

- The HP Column was used for analysis of the samples and temperature was maintained at the range 7000-8000 K for ionization of the elements. 
Table 1. Technical data sheet of the sampling stations indicating their coordinates in space, their name, their depth and their distance from the wild dump (First campaign of sampling)

\begin{tabular}{|c|c|c|c|}
\hline \multirow{2}{*}{$\begin{array}{l}\text { Sample } \\
\text { Number }\end{array}$} & \multicolumn{2}{|c|}{ Coordinates $(\mathrm{km})$} & \multirow{2}{*}{ Place said } \\
\hline & $\mathrm{X}$ & $\mathrm{Y}$ & \\
\hline B1 & 495 & 342.2 & MouAmchane \\
\hline B2 & 494.2 & 343.6 & BouKjor \\
\hline S3 & 494.2 & 342.8 & BouKjor \\
\hline W4 & 495.8 & 342.7 & AnouOmhieff \\
\hline W5 & 469.3 & 342.0 & Ait Bourzouine \\
\hline B6 & 495 & 342.9 & BouKjor \\
\hline W7 & 496.1 & 343.8 & AnouOmhieff \\
\hline B8 & 495.9 & 344.4 & Jebel M'Inegmar \\
\hline W9 & 495.1 & 344.6 & Kef Errih \\
\hline S10 & 496.5 & 343.1 & Ain Boucharmou \\
\hline B11 & 497.5 & 342.2 & Meggardo \\
\hline W12 & 496.2 & 345.1 & Jebel M'Inegmar \\
\hline B13 & 494.8 & 345.1 & Jebel M'Inegmar \\
\hline W14 & 495.8 & 342.8 & Ait Bourzouine \\
\hline S15 & 493.1 & 345.2 & Kef Errih \\
\hline B16 & 494.9 & 341 & MouAmchane \\
\hline W17 & 495.1 & 346.1 & Jebel M'Inegmar \\
\hline W18 & 496.8 & 340.4 & MouAmchane \\
\hline S19 & 493.8 & 346.1 & Kef Errih \\
\hline B20 & 492.9 & 346.5 & Sidi Omar \\
\hline B21 & 494,8 & 340 & MouAmchane \\
\hline W22 & 496.8 & 339.0 & Timlouka \\
\hline W23 & 494.1 & 347.1 & BouTechmadit \\
\hline W24 & 494.2 & 347.7 & BouTechmadit \\
\hline $\mathrm{B} 25$ & 495.6 & 339 & BouIkhba \\
\hline B26 & 492.7 & 345.9 & Kef Errih \\
\hline B27 & 492 & 346.9 & BouTechmadit \\
\hline W28 & 498.9 & 342.2 & BouLàachbt \\
\hline W29 & 497.9 & 339.3 & BouCherme \\
\hline B30 & 492.6 & 347.7 & BouTechmadit \\
\hline S31 & 495.5 & 347 & Jebel M'Inegmar \\
\hline W32 & 496.5 & 337.8 & Ben Darhou \\
\hline W33 & 495.5 & 339.5 & BouIkhba \\
\hline B34 & 494.9 & 344.3 & Mouchenkour \\
\hline B35 & 494.4 & 345.6 & Kef Errih \\
\hline W36 & 496.4 & 340.9 & BouCherme \\
\hline W37 & 495.8 & 342.4 & BouLàachbt \\
\hline S38 & 494.2 & 344 & MouAmchane \\
\hline B39 & 494.4 & 344.7 & Jebel M'Inegmar \\
\hline W40 & 494.2 & 346.5 & Sidi Omar \\
\hline B41 & 495.8 & 343.4 & BouLàachbt \\
\hline W42 & 496.2 & 340 & BouCherme \\
\hline W43 & 495.3 & 341.8 & BouLàachbt \\
\hline
\end{tabular}

B: Borehole, W: Well, S: Source 


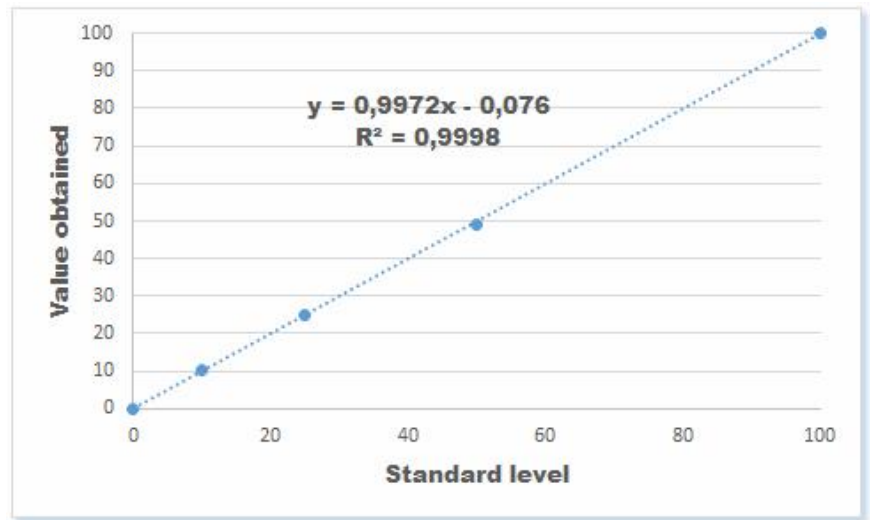

Fig. 2. Graph of the quality assurance/ quality control of sample analysis with ICP-AES

We measured, in the waters via ICP-AES technique, the following heavy metals and metalloids : $\mathrm{Cd}, \mathrm{Cr}, \mathrm{Cu}, \mathrm{Mn}, \mathrm{Ni}, \mathrm{Pb}, \mathrm{As}$, $\mathrm{Zn}, \mathrm{Hg}, \mathrm{Ag}, \mathrm{Sn}$ and Fe, which are the most worrying and already found in high concentrations inthe leachate ofthe wild discharge subject of a previous study (Gamar et al., 2017b).

\section{Results and discussion}

The study of the groundwater analyses of the El Hajeb region has shown that the metals studied here can be classified in increasing order of their relative abundance determined in average concentration as follows: $\mathrm{Hg}<\mathrm{Cd}<\mathrm{As}<\mathrm{Ag}<\mathrm{Pb}<\mathrm{Ni}<\mathrm{Sn}<\mathrm{Cr}$ $<\mathrm{Cu}<\mathrm{Mn}<\mathrm{Zn}<\mathrm{Fe}<\mathrm{B}$ (Table 2). For the cadmium, its contents ranged from $0.0 \mathrm{~g} / \mathrm{L}$ in the wells W29 (depth = 15m; discharge distance $=2042 \mathrm{~m})$ and W32 $($ depth $=28.5 \mathrm{~m}$; distance to the dump $=2152 \mathrm{~m})$ to $5.43 \mathrm{~g} / \mathrm{L}$ in the borehole B8 $($ depth $=14.5 \mathrm{~m}$; distance to the dump $=429.77 \mathrm{~m}$ ) and in well W9 (depth $=16.5 \mathrm{~m}$; distance to the dump $=466.63 \mathrm{~m}$ ). The calculated average was $0.91 \pm 0.12 \mathrm{~g} / \mathrm{L}$ below and very far from the threshold set by the Moroccan standard. In the present study, as the $\mathrm{pH}<8$ therefore the $\mathrm{Cd}^{2+}$ predominates (Hem,1985). As for copper, it is referenced as an undesirable element, but its toxicity is not certain. The results show that its grades ranged from $11.05 \mathrm{~g} / \mathrm{L}$ found in B25 (depth $=30.5 \mathrm{~m}$; distance to the dump $=1624 \mathrm{~m}$ ) to $582.34 \mathrm{~g} / \mathrm{L}$ in the well W37 (depth $=15 \mathrm{~m}$; distance to the dump $=358.06 \mathrm{~m}$ ), while remaining in the guideline of Moroccan standards of $2000 \mathrm{~g} / \mathrm{L}$. Its presence is in relation to the geological environment. A result that is consistent with the work of Mansouri et al. (2014) in wells downstream of municipal solid waste landfill site in the city of Mashhad. These authors found that $\mathrm{Cd}$ and $\mathrm{Cu}$ concentrations in all of the wells did not pose any significant water quality problems since these concentrations were below the standard acceptable levels of drinking water.

Regarding the lead, according to the results, the obtained average was about of $12.99 \pm 2.13 \mathrm{~g} / \mathrm{L}$ (table 2 ). This value greatly exceeded the imperative limit of $1.0 \mathrm{~g} / \mathrm{L}$ set by the Moroccan standard for water intended for human consumption and was slightly above the World Health Organization maximum potable water limits of $10 \mu \mathrm{g} / \mathrm{L}$ (Table 2), making this water unsuitable for drinking. However, this metal was not detected either in the B39 (depth $=31 \mathrm{~m}$; distance to the dump $=504.40 \mathrm{~m}$ ) despite its proximity of the dump, which could be explained by its great depth, nor in the more distant stations (S3, B21, B30, W12 and W36) to the wild dump during the rainy season. The maximum level of $91.11 \mathrm{~g} / \mathrm{L}$ was recorded in drilling B6 (depth = $17 \mathrm{~m}$; distance to the dump $=302.82 \mathrm{~m}$ ) during the dry season, due to its shallow depth and close proximity to the wild dump. The results agree with those from Teta and Hikwa (2017) who monitored metal levels in groundwater from boreholes located in a residential area in the vicinity and downgradient of the landfill within a range of $800-2135 \mathrm{~m}$. These authors reported that groundwater from nearby boreholes had high levels of lead $(\mathrm{Pb})$ and cadmium $(\mathrm{Cd})$, which were negatively correlated to distance from the landfill ( $\mathrm{p}<0.01$ ), indicating that the contamination is from the landfill. By contrast, in Pakistan (Aimanet al.,2016), Pb concentrations were reported higher than the present study.The adverse human health effects of lead include neurological disorders, kidney, and brain damage (WHO, 1993; Mcmichael et al.,1985). Furthermore, Fig. 3 shows that $\mathrm{Pb}$ is negatively correlated with $\mathrm{SO}_{4}\left(\mathrm{R}^{2}=0.7\right)$. The highest concentrations in $\mathrm{Pb}$ were observed in the water deficient in $\mathrm{SO}_{4}$. 
Table 2. Quantification of metallic elements and metalloids in groundwater during the first campaign

\begin{tabular}{|c|c|c|c|c|c|c|}
\hline \multirow{2}{*}{ Parameters } & \multirow{2}{*}{ Mean \pm SE } & \multirow{2}{*}{ Min } & \multirow{2}{*}{ Max } & \multirow{2}{*}{ p-Value } & \multicolumn{2}{|c|}{ Standards } \\
\hline & & & & & WHO & MDW \\
\hline Cadmium (Cd) & $0.91 \pm 0.12$ & 0.00 & 5.43 & $<0.0001$ & 3 & 5 \\
\hline Lead $(\mathrm{Pb})$ & $12.99 \pm 0.13$ & 0.00 & 91.11 & $<0.0001$ & 10 & 1 \\
\hline Arsenic (As) & $4.85 \pm 0.21$ & 2.27 & 8.45 & $<0.0001$ & 10 & 50 \\
\hline Mercury (Hg) & $0.22 \pm 0.01$ & 0.00 & 0.37 & $<0.0001$ & 1 & 1 \\
\hline Silver (Ag) & $8.37 \pm 0.46$ & 7.12 & 12.01 & $<0.0001$ & 10 & - \\
\hline Chromium (Cr) & $83.35 \pm 1.99$ & 0.12 & 254.16 & $<0.0001$ & 50 & 50 \\
\hline Copper $(\mathrm{Cu})$ & $109.29 \pm 2.91$ & 11.05 & 582.34 & $<0.0001$ & 2000 & 2000 \\
\hline Aluminium (Al) & $79.15 \pm 1.7$ & 0.00 & 1340.11 & $<0.0001$ & 200 & - \\
\hline Manganese(Mn) & $126.81 \pm 2.58$ & 15.06 & 663.12 & $<0.0001$ & 400 & 500 \\
\hline Nickel (Ni) & $55.42 \pm 1,02$ & 11.07 & 261.07 & $<0.0001$ & 70 & 20 \\
\hline Zinc (Zn) & $314.66 \pm 4.58$ & 115.4 & 753.60 & $<0.0001$ & 3000 & 3000 \\
\hline $\operatorname{Tin}(\mathrm{Sn})$ & $59.93 \pm 2.7$ & 1.07 & 283.63 & $<0.0001$ & - & - \\
\hline Boron (B) & $0.69 \pm 0.05$ & 0.03 & 1.78 & $<0.0001$ & 2.4 & 0.3 \\
\hline Iron $(\mathrm{Fe})$ & $0.32 \pm 0.04$ & 0.01 & 1.25 & $<0.0001$ & 0.2 & 0.3 \\
\hline
\end{tabular}

MDW :Moroccan Drinking Water (MDW, 2006)

WHO : World Health Organization (WHO, 2011)

Min: Minimal value; Max: Maximal value; Mean: Average value; SE: Standard Error

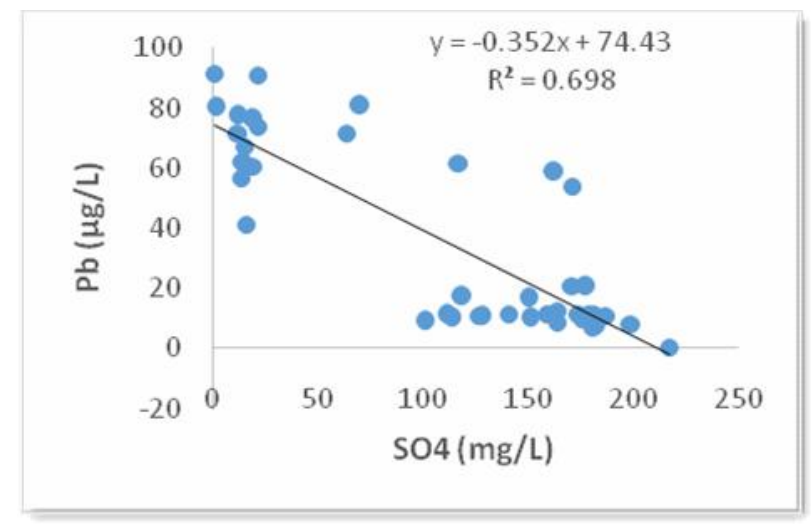

Fig. 3. Scatter diagram of $\mathrm{Pb}$ concentrations as a function of $\mathrm{SO}_{4}$ concentrations during the first campaign of groundwater sampling

The oxidation states of chromium ranging from +2 to +6 but only +3 and +6 are more stable in the environment. The Cr (VI) is more toxic due to carcinogenic and teratogenic effects (Kaim et al.,2013). In present study, chromium levels were highly variable in groundwater and ranged from $0.12 \mathrm{~g} / \mathrm{L}$ recorded in the source S10 (distance to the dump = 508 m) to $254.16 \mathrm{~g} / \mathrm{L}$ in the borehole B2 $($ depth $=13.5 \mathrm{~m}$; distance to the dump $=512.66 \mathrm{~m})$. The calculated average was $83.35 \pm 1.99 \mathrm{~g} / \mathrm{L}$ value higher than $50 \mathrm{~g} / \mathrm{L}$ recommended by Moroccan drinking water standards (MDW, 2006) (Table 2). These results were similar to those found in the study carried out near Municipal Solid Waste Landfill Vientiane,Laos (Vongdala et al,2019). According to these authors, the levels of Cr and $\mathrm{Pb}$ in the groundwater significantly exceeded the basis of WHO in both seasons although noimpact of pollution on the surface water was observed.

For the case of nickel, it is known as a human carcinogen and causes serious health problems (Dieter et al., 2005). Its concentration ranged from $11.07 \mathrm{~g} / \mathrm{L}$ measured in well W28 (depth $=26 \mathrm{~m}$; distance to the dump $=1310 \mathrm{~m})$ and $261.07 \mathrm{~g} / \mathrm{L}$ in wellW9 $($ depth $=$ $16.5 \mathrm{~m}$; distance to the dump $=466.63 \mathrm{~m}$ ) with an average of $55.42 \pm 1.02 \mathrm{~g} / \mathrm{L}$ well above of $20 \mathrm{~g} / \mathrm{L}$ limit set by Moroccan standards. Nonetheless, high concentrations were spotted near the wild landfill. Other studies in Africa found similar results, in Nigeria Michaela et al.(2018) reported that the soil and ground water samples from various sites have a high level of heavy metals concentration as compared to the permissible limits.Concerning the dissolution chemistry relative to chromium and nickel, Fig. 4 indicates that no correlation was observed between $\mathrm{Cr}$ and $\mathrm{pH}\left(\mathrm{R}^{2}=0.15\right)$ for the 43 groundwater stations of the first campaign.

The literature states that an alkaline $\mathrm{pH}$ and an oxygenated medium promote the dissolution of chromium VI (Van Der Putte et al., 
1981). This was not the case here, these groundwater with a low redox potential were under-oxygenated (deeper and/or polluted), suggests that we are in reducing conditions, hence the presence $\mathrm{Cr}$ (III) in abundance. For the Ni, according to the literature his evolution is unpredictable because without the knowledge of the mechanism of dissolution of nickel (and therefore of its chemical form in solution), it is not possible to predict the evolution of its concentration.

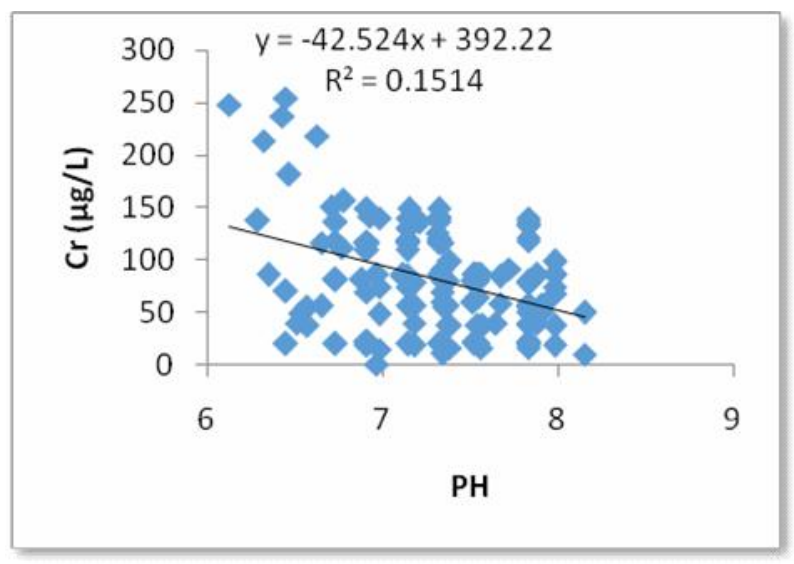

Fig. 4. Scatter diagram of $\mathrm{Cr}$ concentrations as a function of $\mathrm{PH}$ during the firstcampaign of groundwater sampling

For zinc, mercury and arsenic, the threshold values set by the Moroccan standards for the definition of good water are respectively $3000 \mathrm{~g} / \mathrm{L}, 1 \mathrm{~g} / \mathrm{L}$ and $50 \mathrm{~g} / \mathrm{L}$. All 43 points in the sampling network were in norms for these three metals. Although the $\mathrm{Zn}$ shows a high grade, consistent with the observation of Christensen et al. (2001) that $\mathrm{Zn}^{2+}$ usually occurs in orders of magnitude higher than other heavy metals (Table 2),the geochemistry of zinc is relatively uncomplicated and chalcophile behaviour is quite marked by a frequent association with sulphur (Mahan et al.,2017). It should be noted that Zn levels recorded in well water sources close to landfill sites from the Tiruchirappalli District, India (Kanmani and Gandhimathi, 2013) were lesser than those found in this study. By contrast, the concentrations of $\mathrm{Cd}, \mathrm{Pb}, \mathrm{Zn}$, and $\mathrm{Cr}$ in the studied groundwater samples were comparable with earlier studies (Aiman et al., 2016;Chakraborty\&Kumar, 2016;Deshmukh, \&Aher, 2016;Nagarajan et al., 2012; Wijesekara et al.,2014).

The presence in groundwater of As has been reported by other authors in several Moroccan cities, as an example in El Jadida (Chofqi et al., 2007) and abroad in France (Grisey et al., 2010) and in India (Chakraborti et al., 2018). Arsenic is commonly found in the form of sulphur compounds and many metals. The highest concentrations of As have been observed in water deficient in $\mathrm{SO}_{4}$ (Fig. 5). Aluminium and tin were considered undesirable contaminants. For aluminium, its concentration found regularly in groundwater is about $0.4 \mathrm{mg} / \mathrm{L}$. Aluminium is present in soils in the form of the less exchangeable hydroxide, $\left(\mathrm{Al}(\mathrm{OH})_{2}{ }^{+}, \mathrm{Al}(\mathrm{OH})_{2}{ }^{+}\right)$ and insoluble in water. When the $\mathrm{pH}$ value is under 4.5. The $\mathrm{Al}^{3+}$ ion is released by alteration and solubility increases rapidly, increasing the aluminium concentration above $5 \mathrm{mg} / \mathrm{L}$. However, in the presence of suspended solids (high turbidity), it is possible to correlate and determine if the aluminium comes from soils.

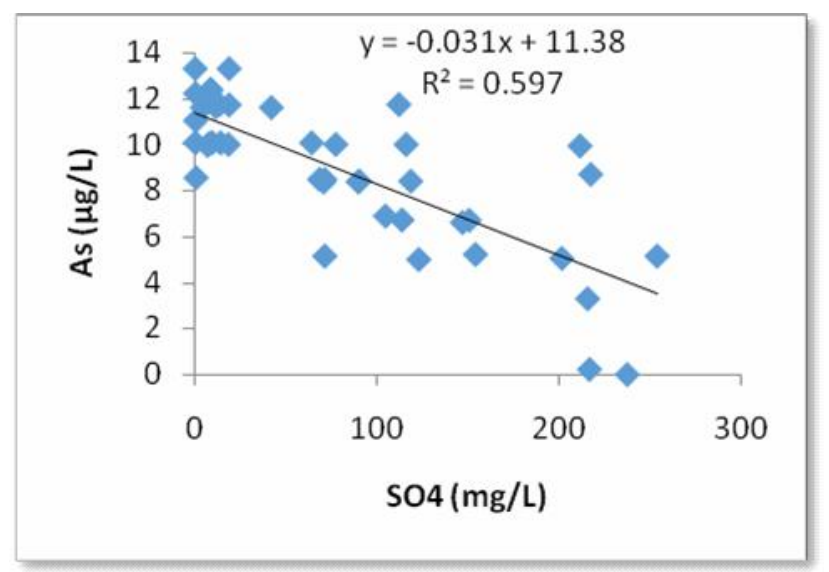

Fig. 5. Scatter diagram of As concentrations as a function of $\mathrm{SO}_{4}$ concentrations during the 1st campaign of groundwater sampling 
The study, conducted for these two metals showed that their contents in groundwater were characterized by a great variability in space and time. Aluminium levels ranged from undetectable to wells W24 (depth = $17 \mathrm{~m}$, distance to the dump $=1907 \mathrm{~m}$ ) and W32 $($ depth $=28.5 \mathrm{~m}$, distance to the dump $=2152 \mathrm{~m})$ to $1.34 \mathrm{mg} / \mathrm{L}$ to boreholes B 1 (depth $=15.5 \mathrm{~m}$, distance to the dump $=462.13 \mathrm{~m})$ and B6 (depth $=17 \mathrm{~m}$, distance to the dump $=302.82 \mathrm{~m})$. While the tin ranged from $1.07 \mathrm{~g} / \mathrm{L}$ in well W29 $(\mathrm{depth}=15 \mathrm{~m}$, distance to the dump $=2042 \mathrm{~m}$ ) to $283.63 \mathrm{~g} / \mathrm{L}$ in borehole B6 (depth $=17 \mathrm{~m}$, distance to the dump $=302.82 \mathrm{~m}$ ). In the absence of Moroccan standards of these two metals, statistics show that $31 \%$ of the groundwater samples exceeded the WHO (2011) standards set.

For iron, it is one of the most abundant metals in the earth's crust. Iron is a trace element essential for human health. Its concentrations, even high, do not pose a risk to human health. However, when its content in water exceeds $0.3 \mathrm{mg} / \mathrm{L}$, iron can change the taste and colour of water, stain washed clothes, and damage household appliances. In this study, its concentrations ranged from $0.01 \mathrm{mg} / \mathrm{L}$ in source $\mathrm{S} 10$ (distance to the dump $=508 \mathrm{~m}$ ) to $1.25 \mathrm{mg} / \mathrm{L}$ found in borehole B2 (depth = $13.5 \mathrm{~m}$; distance to the dump $=512.66 \mathrm{~m}$ ) (table 2). The analyses showed that $14 \%$ of the stations inspected did not comply with Moroccan standards for water intended for human consumption set at $0.3 \mathrm{mg} / \mathrm{L}$. In addition, the concentrations of Fe in the present study were very low that those reported by Chofqi et al. (2004) in well water samples collected from El Jadida (Morocco).

For manganese, high concentrations can cause mental illnesses (ATSDR, 2000; WHO, 1993). In the present study, manganese was found to range from $15.06 \mathrm{~g} / \mathrm{L}$ measured in well W29 (depth $=15 \mathrm{~m}$, distance to the dump $=2042 \mathrm{~m}$ ) to $663.12 \mathrm{~g} / \mathrm{L}$ in $\mathrm{W} 9$ $($ depth $=16.5 \mathrm{~m}$; distance to the dump $=466.63 \mathrm{~m})$ with an average of $126.81 \pm 2.58 \mathrm{~g} / \mathrm{L}$. This average was well below the limit of $500 \mathrm{~g} / \mathrm{L}$ set by the Moroccan standard (Table 2). Results in perfect agreement with those found by Zhai et al.(2019) who found that the concentration of total $\mathrm{Fe}$ and $\mathrm{Mn}$ in the downstream groundwater increased of several orders of magnitude because of the leachate, during a study carried out in NE China.

In addition, the measurements carried out during the first sampling campaign made it possible to see a link between iron and manganese concentrations. The strong positive correlation $\left(\mathrm{R}^{2}=0.73\right)$ indicated that these two metals could have the same origin (Fig. 6). Moreover, the redox potential was weakly negatively correlated with Fe $\left(\mathrm{R}^{2}=0.49\right)($ Fig. 7$)$ and with Mn $\left(\mathrm{R}^{2}=0.52\right)($ Fig. 8). Results in agreement with Virkutyte and Sillanpää(2006) that showed that the variations of Fe and Mn in water are mainly controlled by oxidation-reduction and acid-alkali equilibrium conditions.

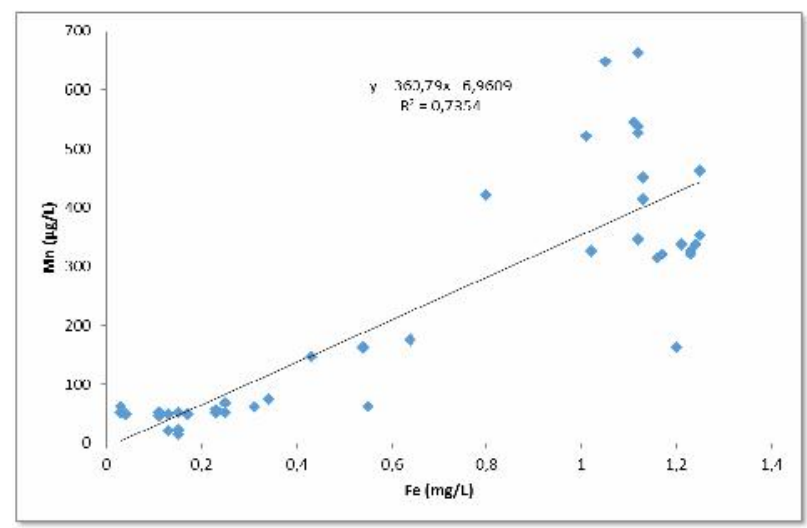

Fig. 6. Scatter diagram of Mn concentrations as a function of Fe concentrations during the first campaign of groundwater sampling

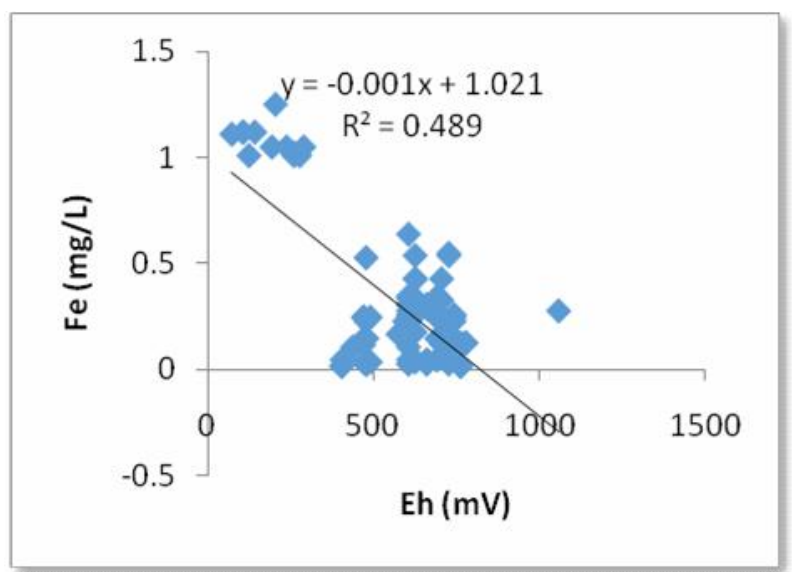

Fig. 7. Scatter diagram of Fe concentrations as a function of Eh during the first campaign of groundwater sampling 


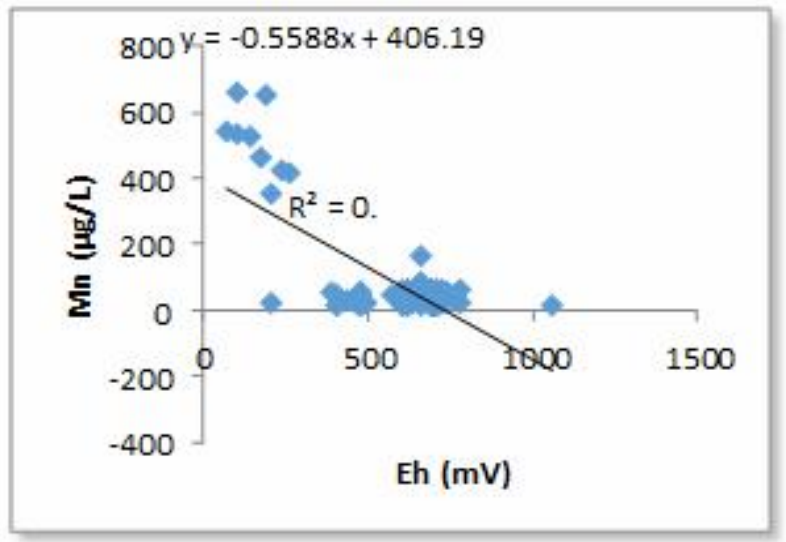

Fig. 8. Scatter diagram of Mn concentrations as a function of Eh during the first campaign of groundwater sampling

On the other hand, the $\mathrm{pH}$ was weakly negatively correlated with the Fe $\left(\mathrm{R}^{2}=0.06\right)($ Fig. 9$)$ and with the Mn $\left(\mathrm{R}^{2}=0.17\right)(\mathrm{Fig}$. 10). The $\mathrm{pH}$ also seems to be a factor controlling more or less the distribution of Fe and Mn. However, under low-pH and low-Eh conditions, the Fe and $\mathrm{Mn}$ concentrations in groundwater were relatively high. These results corroborated those obtained by Pitt et al.(1999) who stated that the Fe and $\mathrm{Mn}$ can be oxidized by anaerobic bacteria and under low-pH conditions, therefore concentrations would increase. While, the $\mathrm{Mn}$ had a positive low correlation $\left(\mathrm{R}^{2}=0.28\right)$ with sulphates (Fig. 11) and even less between $\mathrm{Fe}$ and $\mathrm{SO}_{4}\left(\mathrm{R}^{2}=0.02\right)$ (Fig. 12), which is not in agreement with Olías et al.(2004), who found that Mn had a strong correlation with sulphates resulting from sulphide oxidation.The last metal sought in this study was silver (Ag). The Ag content in groundwater ranges from $7.12 \mathrm{~g} / \mathrm{L}$ in well W33 (depth $=13.5 \mathrm{~m}$; distance to the dump $=1480 \mathrm{~m}$ ) during the wet season to 12.01

$\mathrm{g} / \mathrm{L}$ recorded at well $\mathrm{W} 23$ (depth $=24.5 \mathrm{~m}$; distance to the dump $=1854 \mathrm{~m}$ ) during the dry season with an average of $8.37 \pm 0.46 \mathrm{~g} / \mathrm{L}$.

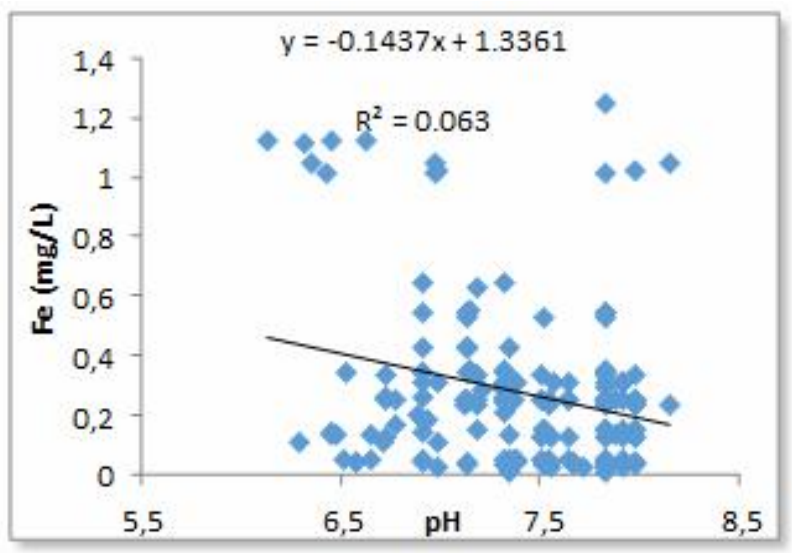

Fig. 9. Scatter diagram of Fe concentrations as a function of $\mathrm{pH}$ during the first campaign ofgroundwater sampling

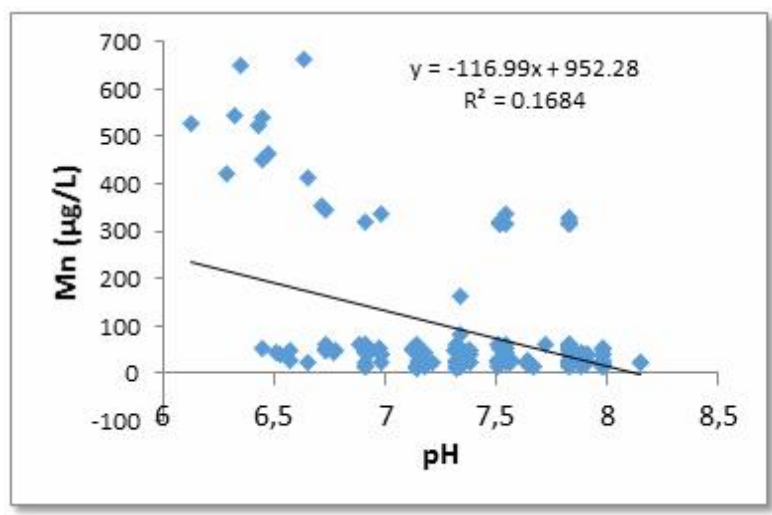

Fig. 10. Scatter diagram of $\mathrm{Mn}$ concentrations as a function of $\mathrm{pH}$ during the first campaign of groundwater sampling 
In the absence of a Moroccan standard, the WHO (2011) standard stipulates that water of optimal quality to be consumed must not exceed the concentration of $10 \mathrm{~g} / \mathrm{L}$. Statistics show that $33 \%$ exceed this standard. The field survey indicated that this pollution is related to the practice of cloud seeding since decades to combat drought. Each year, it releases a large amount of chemical particles including silver iodide (AgI) and sodium iodide (NaI) sprayed to inseminate the clouds and therefore to increase the rate of precipitation in the atmosphere. These particles reach the water table and accumulate there.

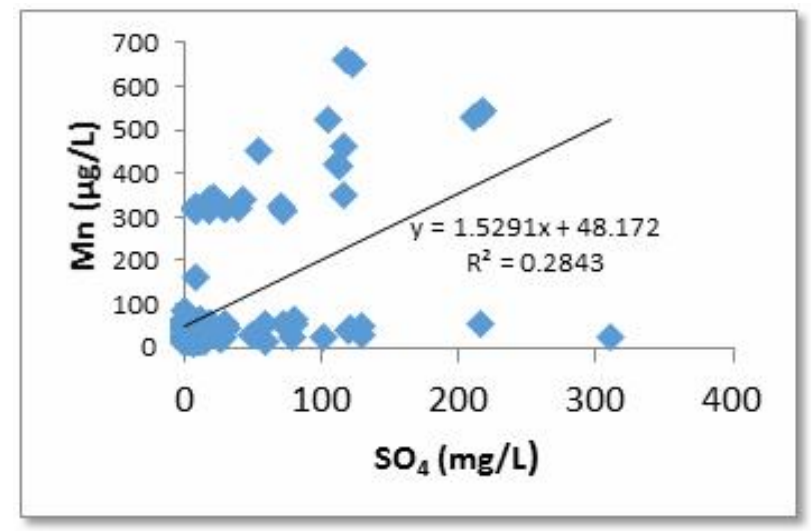

Fig.11. Scatter diagram of $\mathrm{Mn}$ concentrations as a function of $\mathrm{SO}_{4}$ concentrations during the first campaign of groundwater sampling

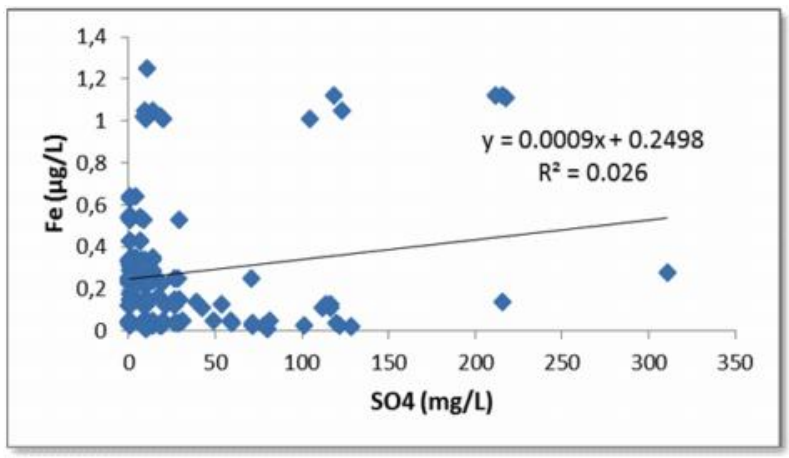

Fig.12. Scatter diagram of $\mathrm{Fe}$ concentrations as a function of $\mathrm{SO}_{4}$ concentrations during the first campaign of groundwater sampling

\section{Conclusion}

This study is the first to examine the heavy metals and metalloids contamination of water in vicinity the wild landfill of El Hajeb (Morocco). It provided detailed information of pollution presence by the metals and metalloids and as well as their levels and revealed that the groundwater covering most of the water resources near the wild dump is contaminated and generally appears of poor quality. Indeed, the investigations carried out on groundwater unequivocally have revealed the presence of pollution especially in $\mathrm{Cd}, \mathrm{Cr}, \mathrm{Al}, \mathrm{Mn}, \mathrm{Ni}, \mathrm{Fe}$ and $\mathrm{Pb}$, which are mainly linked to the leachate of the wild landfill and, a lesser degree, to the excessive and irrational use of chemical fertilizers and phytosanitary products.

On the other hand, some high correlations have been revealed, as the lead and Arsenic that are negatively correlated with $\mathrm{SO}_{4}$ and have been observed in water deficient in $\mathrm{SO}_{4}$ and the strong positive correlation between $\mathrm{Fe}$ and $\mathrm{Mn}$, which indicated that these two metals could have the same origin. For metal of silver, his detection is probably related to the practice of cloud seeding that the region has known for decades.

At the end of this study, and in order to contribute to sustainable development in the region and to improve the quality of life of citizens through respect for the environment, we would like to make the following suggestions:

-Urgently undertake the rehabilitation work or the closure of the landfill and the opening of another controlled;

-Establish a system of continuous monitoring of groundwater quality in the study area.

\section{References}

Ackah M., Agyemang O., Anim A.K., Osei J., Bentil N.O., Kpattah L., Gyamfi E.T., Hanson J.E.K. 2011. Assessment of groundwater quality for drinking and irrigation: the case study of Teiman-Oyarifa Community, Ga East Municipality, Ghana. Proceedings of the International Academy of Ecology and Environmental Sciences, Vol. 1, pp. 186-194. 
Gamar et al. / International Journal of Engineering, Science and Technology, Vol. 12, No. 4, 2020, pp. $41-53$

Adamcová D., Radziemska M., Ridošková A., Bartoň S., Pelcová P., Elbl J., Kynický J., Brtnický M., Vaverková M.D. 2017. Environmental assessment of the effects of a municipal landfill on the content and distribution of heavy metals in Tanacetum vulgare L. Chemosphere, Vol. 185, pp. 1011-1018. https://doi.org/10.1016/j.chemosphere.2017.07.060

Aiman, U., Mahmood, A., Waheed, S., Malik, R.N. 2016. Enrichment, geoaccumulation and risk surveillance of toxic metals for different environmental compartments from Mehmood Booti dumping site, Lahore city, Pakistan. Chemosphere, Vol. 144, pp.2229-2237. https://doi.org/10.1016/j.chemosphere.2015.10.077

ATSDR. 2000. Toxicological profile for manganese, Atlanta, GA, United States Department of Health and Human Services, Public Health Service, Agency for Toxic Substances and Disease Registry.

Awasthi, A.K., Zeng X., Li, J. 2016. Environmental pollution of electronic waste recycling in India: a critical review. Environmental Pollution, Vol. 211, pp. 259-270. https://doi.org/10.1016/j.envpol.2015.11.027

Boateng, T.K., Opoku, F., Akoto, O. 2019. Heavy metal contamination assessment of groundwater quality: a case study of Oti landfill site, Kumasi, Applied Water Science, Vol. 9 pp. 33, http://dx.doi.org/10.1007/s13201-019-0915-y.

Chakraborti, D., Singh, S.K., Rahman, M.M., Dutta, R.N., Mukherjee, S.C., Pati S. and Kar, P.B. 2018. Groundwater Arsenic Contamination in the Ganga River Basin: A Future Health Danger, International Journal of Environmental Research and Public Health, Vol.15, pp. 180. doi: 10.3390/ijerph15020180

Chakraborty, S. and Kumar, R.N. 2016. Assessment of groundwater quality at a MSW landfill site-using standard and AHP based water quality index: a case study from Ranchi, Jharkhand, India. Environmental Monitoring and Assessment, Vol. 188, pp. 1-18. https://doi.org/10.1007/s10661-016-5336-x

Chary, N.S., Kamala, C., Raj, D.S. 2008. Assessing risk of heavy metals from consuming food grown on sewage irrigated soils and food chain transfer. Ecotoxicology and Environmental Safety, Vol. 69, pp. 513-524. https://doi.org/10.1016/j.ecoenv.2007.04.013

Chofqi, A.,Younsi, A., Lhadi, E., Mania, J., Mudry J., Veron, A. 2007. Lixiviat de la DéchargePubliqued'ElJadida (Maroc): Caractérisation et Etude d'Impact sur la Nappe Phréatique, Revue Francophone D'écologieIndustrielle (In French), Vol. 46, pp. 4-10.

Christensen, T. H., Kjeldsen, P., Bjerg, P.L., Jensen, D. L., Christensen, J. B., Baun, A., Albrechtsen H.and Heron, G. 2001. Biogeochemistry of landfill leachate plumes. Applied Geochemistry, Vol. 16, No. 7-8, pp. 659-718. https://doi.org/10.1016/S0883-2927(00)00082-2

Deshmukh, K.K. and Aher, S.P. 2016. Assessment of the impact of municipal solid waste on groundwater quality near the Sangamner city using GIS approach. Water Resources Management, Vol. 30, pp. 2425-2443. https://doi.org/10.1007/s11269016-1299-5

Dieter, H.H., Bayer T.A. and Multhaup, G. 2005. Environmental copper and manganese in the pathophysiology of neurologic diseases (Alzheimer's disease and Manganism). Acta Hydrochimica and Hydrobiologica, Vol. 33, pp. 72-78. https://doi.org/10.1002/aheh.200400556

Elder, J.F. 1988. Metal Biogeochemistry in Surface-Water System - A review of Principles and Concepts. 1013, United States Geological Survey.

Erses, A.S., Onay, T.T. 2003. In situ heavy metal attenuation in landfills under methanogenic conditions, Journal of Hazardous Materials, Vol. 99, pp. 159-175. doi: 10.1016/s0304-3894(02)00354-0

Esakku, S., Palanivelu, K., Joseph, K. 2003. Assessment of heavy metals in a municipal solid waste dumpsite.In Proceedings of the Workshop on Sustainable Landfill Management, Chennai, India, Vol. 35, pp. 139-145.

Gamar, A., Khiya, Z., Zair, T., El Kabriti, M., Bouhlal A., and El Hilali, F. 2017a. Assessment of physicochemical quality of the polluting load of leachates from the wild dump of El Hajeb City (Morocco). International Journal of Research Granthaalayah, Vol. 5, pp. 63-71.

Gamar, A., Khiya, Z., Zair, T., El Kabriti, M., Bouhlal, A., El Hilali, F. 2017b. Ecotoxicological risk Assessment of heavy metals from leachate of the wild landfill of El Hajeb city (Morocco), International Journal of Scientific \& Technology Research, Vol. 6, pp. 166-171.

Gamar, A., Zair, T., El Hilali, F., 2017c. Leachates from the wild discharge of El Hajeb-city (Morocco): analytical assessment of quality microbiological and sanitary risks. International Journal of ChemTech Research, Vol. 10, pp. 273-282.

Gamar, A., Khiya, Z., Zair, T., El Kabriti, M., Bouhlal, A., El Hilali, F. 2017d. Temporal evolution of the physicochemical and biological leachate quality from the discharge public of El Hajeb town (Morocco). International Journal of Research Science \& Management, Vol. 4, pp. 25-36.

Gamar, A., Zair, T., El Kabriti, M., El Hilali, F. 2018. Study of the impact of the wild dump leachates of the region of El Hajeb (Morocco) on the physico-chemical quality of the adjacent water table. Karbala International Journal of Modern Science, Vol. 4, No. 4, https://doi.org/10.1016/j.kijoms.2018.10.002.

Grisey, A., Tisiot, R., Powaga, E. 2010. Energie sous serre - Présentation du projetserrecapteurd'énergie, Infos Ctifl, Vol. 262, pp. 32-36.

Guidelines for drinking-water quality, Recommendations, 1993. Geneva, Switzerland: World Health Organization. $2 n d$ ed. Vol. 1, p. 11. 
Gamar et al. / International Journal of Engineering, Science and Technology, Vol. 12, No. 4, 2020, pp. 41-53

Hem, J. D. 1985. Study and interpretation of the chemical characteristics of natural water, USGS Water Supply Paper, Vol. 2254, pp. 117-120.

Kaim, W., Schwederski, B., \& Klein, A. 2013. Bioinorganic Chemistry--Inorganic Elements in the Chemistry of Life: An Introduction and Guide. John Wiley \& Sons.

Kanmani, S., Gandhimathi, R. 2012. Assessment of heavy metal contamination in soil due to leachate migration from an open dumping site. Applied Water Science, Vol. 13, pp. 193-205. https://doi.org/10.1007/s13201-012-0072-z

Kanmani, S. and Gandhimathi, R., 2013. Investigation of physicochemical characteristics and heavy metal distribution profile in groundwater system around the open dumpsite. Applied Water Science, Vol. 3, pp. 387-399. https://doi.org/10.1007/s13201013-0089-y

Larocque, A.C. and Rasmussen, P.E. 1998. An overview of trace metals in the environment: Mobilization to remediation, Environmental Geology, Vol. 33, pp. 85-91. https://doi.org/10.1007/s002540050227

Liao, P., Yuan, S., Wang, D. 2016. Impact of redox reactions on colloid transport in saturated porous media: an example of ferrihydrite colloids transport in the presence of sulphide. Environmental Science and Technology, Vol. 50 pp. 10968-10977. https://doi.org/10.1021/acs.est.6b02542

Ma, W., Tai, L., Qiao, Z., Zhong, L., Wang, Z., Fu, K., Chen, G. 2018. Contamination source apportionment and health risk assessment of heavy metals in soil around municipal solid waste incinerator: a case study in North China. Science of the Total Environment, Vol. 631, pp. 348-357. https://doi.org/10.1016/j.scitotenv.2018.03.011

Mahan, B., Siebert, J., Pringle, E.A., and Moynier, F. 2017. Elemental partitioning and isotopic fractionation of Zn between metal and silicate and geochemical estimation of the S content of the Earth's core, Geochimica et Cosmochimica Acta, Vol. 196, pp. 252-270. https://doi.org/10.1016/j.gca.2016.09.013

Mansouri, B., Salehi, J., Rezaei, M. 2014. Leachate and pollution levels of heavy metals in the groundwater near municipal solid waste landfill site of Mashhad (Iran), Iranian Journal of Toxicology, Vol. 8, pp. 1068-1072.

McMichael, A.J., Baghurst, P.A., Robertson, E.F., Vimpani, G., Wigg, N.R. 1985. The port pirie cohort study: blood lead concentrations in early childhood. The Medical Journal of Australia, Vol. 143, pp. 499-503.

MDW. 2006. Moroccan Drinking Water Standards in Force since Relating to the Quality of Human Feed Water Taken from the Official Bulletin No. 5404, 16 March 2006 (NM 03.7.001) and the Simplified Quality Grids Set for the Assessment of the Overall Quality of Groundwater by Order No. 1275-02 of 17 October 2002.

Michael, E.I., Odoh, A.O., Chukwura, E.I., Ben, M.G. 2018. Heavy metal and microbial load properties of dumpsite leachate: Case study of Onitsha dumpsite, south-east, Nigeria. Journal of Toxicological Analysis, Vol.1, pp.6.

Nagarajan, R. Thirumalaisamy, S. Lakshumanan, E. 2012. Impact of leachate on groundwater pollution due to non-engineered municipal solid waste landfill sites of erode city, Tamil Nadu, India. Iranian Journal of Environmental Health Science \& Engineering, Vol. 9, pp. 1-12. https://doi.org/10.1186/1735-2746-9-35

Nica, D.V., Bura, M., Gergen, I., Harmanescu, M., Bordean, D. 2012. Bioaccumulative and conchological assessment of heavy metal transfer in a soil-plant-snail food chain. Chemistry Central Journal, Vol. 15, pp.1-15. https://doi.org/10.1186/1752153X-6-55

Olías, M., Nieto, J.M., Sarmiento, A.M., Cerón J.C. and Cánovas, C.R. 2004. Seasonal water quality variations in a river affected by acid mine drainage: the Odiel River (South West Spain). Science of the Total Environment, Vol. 333, No. 1-3, pp. 267-281. doi: 10.1016/j.scitotenv.2004.05.012

Oyeku O., Eludoyin A. 2010. Heavy metal contamination of groundwater resources in a Nigerian urban settlement. African Journal of Environmental Science and Technology, Vol. 4, No. 4, pp. 201-214.

Pitt, R., Clark, S., Field, R. 1999. Groundwater contamination potential from stormwater infiltration practices. Urban Water Journal, Vol. 1, pp. 217-236.

Prater, B.E. 1975. The metal content and characteristics of steelwork's effluents discharging to the Tees estuary. Water Pollution Control, Vol. 74, pp. 63-78.

Samadder, S., Prabhakar, R., Khan, D., Kishan, D., Chauhan, M. 2017. Analysis of the contaminants released from municipal solid waste landfill site: a case study. Science of the Total Environment, Vol. 580 pp. 593-601. https://doi.org/10.1016/j.scitotenv.2016.12.003

Sayyed, M.R.G. and Sayadi, M.H. 2011. Variations in the heavy metal accumulations within the surface soils from the Chitgar industrial area of Tehran, Proceedings of the International Academy of Ecology and Environmental Sciences, Vol. 1, pp. 3646.

Slack, R.J. Gronow, J.R. Voulvoulis, N. 2005. Household hazardous waste in municipal landfills: Contaminants in leachate. Science of the Total Environment, Vol. 337, No. 1-3, pp. 119-137. https://doi.org/10.1016/j.scitotenv.2004.07.002

Teta, Ch., Hikwa, T., 2017. Heavy metal contamination of ground water from an unlined landfill in Bulawayo, Zimbabwe, Journal of Health and Pollution, Vol. 7, No. 15, pp. 18-27. https://doi.org/10.5696/2156-9614-7.15.18

US Environmental Protection Agency. 2002. National primary drinking water standards. EPA/816-F-02-013, [Online]. Available : http://www.epa.gov/safewater.

Van Der Putte, I., Brinkhorst, M.A., Koeman, J.H. 1981a. Effect of pH on the acute toxicity of hexavalent chromium to rainbow 
Gamar et al. / International Journal of Engineering, Science and Technology, Vol. 12, No. 4, 2020, pp. $41-53$

trout (Salmo gairdneri), Aquatic Toxicology, Vol. 1, No. 2, pp. 129-142. https://doi.org/10.1016/0166-445X(81)90035-7

Veron, A. 2004. Environmental impact of an urban landfill on a coastal aquifer (El Jadida, Morocco). Journal of African Earth Sciences, Vol. 39, No. 3-5, pp. 509-516. https://doi.org/10.1016/j.jafrearsci.2004.07.013

Virkutyte, J. and Sillanpää, M. 2006. Chemical evaluation of potable water in Eastern Qinghai Province, China: Human health aspects, Environment International, Vol. 32, pp. 80-86. https://doi.org/10.1016/j.envint.2005.05.022

Vongdala, N., Tran, H.D., Xuan, T.D., Teschke, R., and Khanh, T.D. 2019. Heavy metal accumulation in water, soil, and plants of municipal solid waste landfill in Vientiane, Laos, International Journal of Environmental Research and Public Health, Vol. 16, pp. 22, http://dx.doi:10.3390/ijerph16010022.

Wasserman, G.A., Liu, X., Parvez, F., Ahsan, H., Levy, D., Factor-Litvak, P., Kline. J., van Geen, A., Slavkovich, V., LoIacono, N.J., Cheng, Z., Zheng, Y., and Graziano, J.H. 2006. Water manganese exposure and children's intellectual functions in Araihazar, Bangladesh. Environmental Health Perspectives, Vol. 114, pp. 124-129. doi: 10.1289/ehp.8030

WHO. 2011. Guidelines for Drinking-Water Quality, fourth edition, Library Catalo-guing-in-Publication Data Guidelines for Drinking-Water Quality. 4th ed.

WHO. 2008. Guidelines for drinking-water quality, Third Edition, World Health Organization. Geneva.

Wijesekara, S., Mayakaduwa, S.S., Siriwardana, A., de Silva, N., Basnayake, B., Kawamoto, K., Vithanage, M. 2014. Fate and transport of pollutants through a municipal solid waste landfill leachate in Sri Lanka. Environmental Earth Sciences, Vol. 72, pp.1707-1719. https://doi.org/10.1007/s12665-014-3075-2

Wittsiepe, J., Feldt, T., Till, H., Burchard, G., Wilhelm, M., Fobil, J.N. 2017. Pilot study on the internal exposure to heavy metals of informal level electronic waste workers in Agbogbloshie, Accra, Ghana. Environmental Science and Pollution Research International, Vol. 24, pp. 3097-3107. doi: 10.1007/s11356-016-8002-5

Zhai, Y., Ma, T., Zhou, J., Li, X., Liu, D., Wang, Z., Qin, Y., Du, Q. 2019. Impacts of leachate of landfill on the groundwater hydrochemistry and size distributions and heavy metal components of colloids: a case study in NE China, Environmental Science and Pollution Research, Vol. 26, pp. 5713-5723. http://dx. doi.org/10.1007/s11356-018-4053-0.

\section{Biographical notes}

A. Gamar is a member of the Research team of Chemistry of the Bioactive Molecules and the Environment Department of Chemistry, Moulay Ismail University, Faculty of Sciences, ZitouneMeknes, Morocco

T. Zair is at the Laboratory of Chemistry of Materials and Biotechnology of Natural Products (Chima-Bio) Department of Chemistry, Moulay Ismail University, Faculty of Sciences, ZitouneMeknes, Morocco

El Kabriti is at the National Laboratory of the Studies and the Monitoring of the Pollution (NLSMP),Ministry Delegate in Charge of the Environment Morocco Al Irfane-City, Rabat, Morocco.

F. El Hilali is a member of the Research team of Chemistry of the Bioactive Molecules and the Environment Department of Chemistry, Moulay Ismail University, Faculty of Sciences, ZitouneMeknes, Morocco. El Hilali is also of the Laboratory of Chemistry of Materials and Biotechnology of Natural Products (Chima-Bio) Department of Chemistry, Moulay Ismail University, Faculty of Sciences, ZitouneMeknes, Morocco 